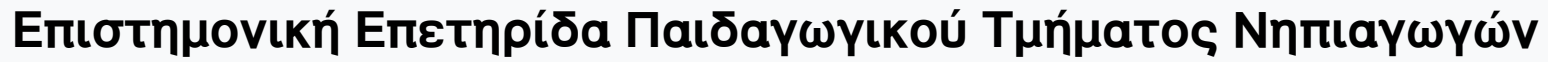 חavertotnuíou Iwavvívwv
}

Tóp. 6 (2013)

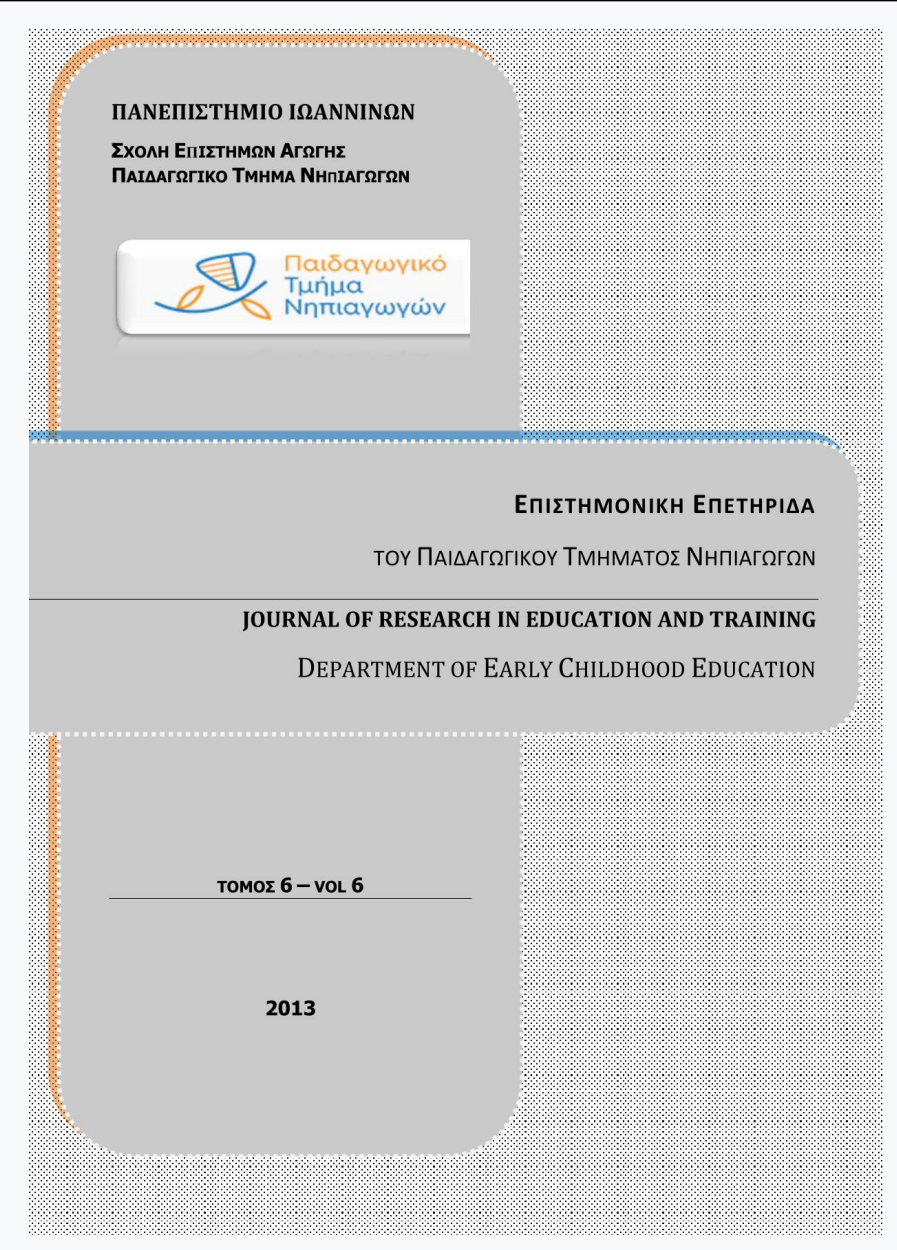

Teachers' professional development: The case of Lithuania

Leta Dromantiene, Valdone Indrašiene, Odeta Merfeldaite, Romas Prakapas

doi: $\underline{10.12681 / \text { jret.760 }}$

Copyright @ 2013, Leta Dromantiene, Valdone Indrašiene, Odeta Merfeldaite, Romas Prakapas

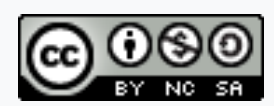

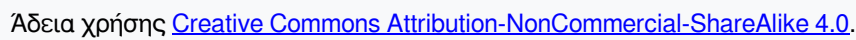

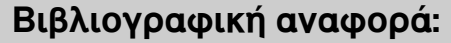

Dromantiene, L., Indrašiene, V., Merfeldaite, O., \& Prakapas, R. (2013). Teachers' professional development: The case

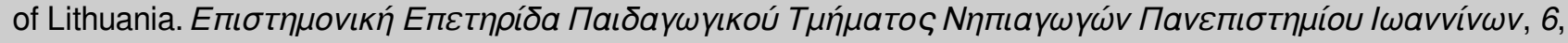
202-215. https://doi.org/10.12681/jret.760 


\title{
Teachers' Professional Development: The Case of Lithuania
}

\section{Leta Dromantienè, Valdonè Indrašienè, Odeta Merfeldaitè, Romas Prakapas}

\begin{abstract}
Lifelong learning paradigm raises higher requirements for a teacher: quality and effectiveness are the two key words defining the general education policy of the $\mathrm{EU}$ and the main objectives of the current period. Today teachers are required to be able to work in a multicultural environment, flexibly respond and adapt to changes, individualise and differentiate the content of education, and pursue various social functions (such as vocational counseling, conflict management, mediation etc.). Besides high professional requirements teachers are also required to participate in the continuous/further learning process including formal/nonformal professional development, self-education, and studies in state and private vocational training organisations not only within the framework of education but also in other spheres. The following question have been raised in the article: how the process of teachers' professional development is organised in Lithuania?
\end{abstract}

KEY WORDS: teacher, educator, professional development, lifelong learning, qualification requirements, competence, qualification improvement, programmes for training. 


\section{INTRODUCTION}

The development of a process and system of adult education has gained a particular importance in the world, as well as in Lithuania. The European Union has set the goal of raising the number of adults participating in lifelong learning (Dromantienè et al, 2009: 6). Demographic factors (e.g., the preponderance of older people) have caused people to stay in the labour market longer, and both the rapid development of technologies and the increase in required information necessitate continuous learning. As a member of the European Union, both the Lithuanian government and its citizens face many challenges and must acquire the ability to meet new responsibilities. The development of in-service training has become very important in order to stay in employment and to successfully pursue a career (Dromantiene, Zemaitaityte, 2010: 183).

Teachers, school leaders and teacher trainers are the key factors determining the improvement and development of education and teacher education system. Changes in the education system and society impose new requirements to the profession of teachers. Today teachers are required not only to convey the basic knowledge but also to help young people learn independently, i.e. acquire the main skills rather than memorise information; teachers are encouraged to use constructive and cooperative teaching methods and act as mediators and class tutors rather than authorised instructors (Rutkienè, Zuzevičiūtè, 2009).

The Council of the European Union (hereinafter referred to as the EU), the EU Commission and other concerned European institutions highlight that high level teacher training and further professional development is not only a guarantee of success of the entire education system but also one of the main factors ensuring economic-social welfare of Member States and sustainable development of these countries.

One of the objectives of the National Lisbon Strategy Implementation Programme (2005) was to upgrade teachers' competences. In view of this, it is anticipated to „Prepare and submit to the Government of the Republic of Lithuania a draft National Reform Programme for Teachers Initial and Continuous Training and to implement

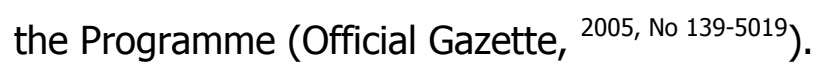


Pursuant to the Lithuanian Strategy of Securing Lifelong Learning (Official Gazette, 2008, No 122-4647), teachers should be provided with a possibility to continuously improve their professional skills. Par.13.2 of the document says that "the main focus in the sphere of developing lifelong learning should be placed on continuing competence learning, which should be acquired by pedagogues engaged in all fields of education. This competence should also be developed by pupils as early as during the stage of general education." One of the main objectives of the Strategy of Securing Lifelong Learning is to create conditions for persons of different needs and abilities not only to acquire, but also upgrade "qualification and competencies facilitating the placement and setting into the labour market, guaranteeing the progress of the national economy, its competitiveness and sustainable development."

Development of teachers' qualification as the main factors of the Lithuanian education system is highlighted in the National Education Strategy for 2013 - 2022: „education shall open the opportunities and propose various services facilitating the development of personal abilities based on professional qualifications and selfeducation, trust in own abilities, self-responsibility and responsibility for the community, the state and the environment"(2012). In view of this the first objective of the Strategy is to develop the community of pedagogues consisting of reflecting teachers involved in the continuous education process and achieving good results.

Problematic issues: What is the actual state of teacher's professional development in Lithuania? How is professional development for educators modeled in Lithuania?

The aim of the Article: to discuss certain aspects in organising professional development of pedagogues in Lithuania.

Object of the Research: organisation of teacher's professional development.

Research methodology: the research was carried out in January 2012 - April 2012. In order to analyse the current situation in organising professional development of pedagogues in Lithuania, the analysis of secondary sources was carried out and included the investigation of the scientific books and journals, the Internet data and regulatory enactments. The analysis was also based on the 
personal experience of the authors. The selected research-related information sources ensure reliability and relevance of information.

\section{REFORM OF THE LITHUANIAN EDUCATION SYSTEM}

In Lithuania teachers' qualification development is a constituent part of the education system. When considering Lithuania's education as a cultural and social phenomenon, it is important to note that education reform has commenced before the restoration of Lithuania's Independence. In other words this reform has become one of the prerequisites for restoration of Independence of the State. In 1988, the reform of Lithuania's education started. The principles of reformation of the Lithuanian education system were declared to be national affinity, democracy, humanity and change.

The Concept of Education in Lithuania declared back in 1992 marked the transformation of values and paradigms, i.e. transition from the classical to free educational paradigm. According to P. Radó (2003), it was a transition from the command to the demand-driven system. K. Trakšelys (2011) says that taking account of social, economic and political changes, it was necessary also to reorganise social institutes, including the education system which has great influence on an individual and plays a very important role in personality development.

The reform sought to reach specific goals. The main goal of the educational reform is an independent and creative individual, whose full potential emerges in school. Educational reform should help an individual flourish in social and cultural spheres and cultivate his/her cultural identity and understanding that he/she is not only a consumer of native culture, but also a creator responsible for the development and preservation of nature. Educational goals: to help an individual discover universal human values and base his/her life upon them; to foster the abilities of a critically thinking person to evaluate existential questions, make responsible decisions and act independently; to foster an individual who is prepared for professional work, determined and able to adapt to an ever-changing social and economic environment and participate in its betterment, to develop an individual's national and cultural consciousness; to develop an individual's democracy values; to raise awareness of Lithuanian citizens) based on the key national and European cultural values (The absolute value of an individual, neighbourly love, innate equality of all human beings, 
freedom of conscience, tolerance, and affirmation of democratic social relations. At the core of a nation's independent and full-fledged life is an individual who is educated in the spirit of educational reform, is mature and dedicated to the new historic period of national development, is able to make independent decisions, is active member of the society, bases his/her worldview on national and key human values, is able to competently and responsibly participate in the creation and development of a democratic society and the state) (The Concept of Education in Lithuania, 1992).

Adult education policy in Lithuania is shaped in accordance with the functioning laws and strategies, i.e.: The Republic of Lithuania Law on Education (2011), The National Education Strategy for 2013-2022 (2013), The Lifelong Learning Strategy (2008). It is obvious that teachers are the key factors determining the development of the education system and teacher training system.

\section{CHALLENGES FOR TEACHERS' PROFESSIONAL DEVELOPMENT}

Quality and effectiveness are the two main key words defining the common European Union education policy and its main objectives. These objectives are ambitious and not easily achieved, especially regarding the requirements to teachers. It is not enough to be a professional of own subject and have an extensive knowledge of pedagogy and psychology. Teachers are required to be able to work in various cultural and multicultural environments, to be flexible and respond to changes, to individualize and differentiate the curriculum, and to perform several social functions (as a professional consultant, conflict mediator, etc.).

For persons who have worked as teachers during their entire life attending professional development seminars is not merely a goal, but a necessity. This has been declared by more than 20 European countries. Teachers have many various opportunities to improve the quality of their work. They gain on-the-job experience every day; they use the professional literature, collaborate with colleagues and learn from them, participate in the courses and seminars, continue the studies in the university etc. "The learning society, it must be recognized, is learner based, has no barriers of access and provides a flexible but lifelong system of education" (Jarvis, 1997). 
Professional development models in the EU Member States vary from country to country depending on the national situation, the needs and traditions. These models are constantly changing following the changes in the education policy, expectations and desires of pedagogues. However, not all countries enforce these forms of professional development in an official manner nor do they make them required. For example, in the Netherlands, Sweden, Island, and Norway teachers are free to pursue professional development activities. In Spain, Luxembourg, Poland, Portugal, Slovenia and Slovakia there is no requirement to upgrade teacher qualifications; but the career of a teacher and higher remuneration is related to the continuous professional development (Tuovinen, 2008; Ross, Hutchings, 2003; Stylianidou et all, 2004; Murphy and Coolahan, 2003; Teachers professional development. Europe in international comparison 2010).

Although it is believed that traditional methods of professional development (e.g. seminars and university courses) are tiresome, the duration of studies (not the form) has major impact on the professional development of teachers. The duration must be sufficient so as to have enough time for the acquisition of new information and its application in practice. Participation in the professional development of groups of teachers or even of the entire school community ensures better results and longlasting affect. A match between the learning supply and demand also contributes to the above results: teachers are involved in the learning process and are more likely to apply the acquired knowledge in their work with the classroom. They search for relevant information, carry out research, experiments, and are involved in the creative activities.

As in other East European countries while education reform was underway the system of teachers' qualification improvement was changing. In 1992 pedagogue qualification improvement was decentralized. In addition to a few existing qualification improvement institutes that were governed centrally, regional education centres, specialized qualification improvement centres and qualification improvement centres in higher education institutions sprang up (Pečiulianskienè, 2005). The implementation of the programme of State pedagogue training and qualification improvement reform started in 2006. Its purpose was that pedagogue training and qualification improvement system would be in line with the needs of educational system and society of Lithuania. The EU structural support has given a strong push 
to the implementation of this program. The support enabled to begin the reform of pedagogue qualification improvement system in order to ensure the quality of the activity of modern regional pedagogue qualification improvement system and guarantee to all the pedagogues of Lithuania equal opportunities to acquire new competencies needed for social and professional life. At the present time the 2nd stage of the project "The Development of the System of Pedagogue Qualification Improvement and Reskilling" funded by the EU is being implemented in Lithuania since 2010.

Table 1. The Change of the Number of Teachers and Schools in 2006-2012

\begin{tabular}{|l|c|c|c|c|c|c|}
\hline Years & $2006-2007$ & $2007-2008$ & $2008-2009$ & $2009-2010$ & $2010-2011$ & $2011-2012$ \\
\hline Teachers & $\mathbf{4 3 3 3 1}$ & $\mathbf{4 2 2 6 7}$ & $\mathbf{4 0 7 4 5}$ & $\mathbf{3 9 3 2 8}$ & $\mathbf{3 7 5 6 0}$ & $\mathbf{3 6 8 2 3}$ \\
\hline Schools & $\mathbf{1 4 7 7}$ & $\mathbf{1 4 4 8}$ & $\mathbf{1 3 8 9}$ & $\mathbf{1 3 3 6}$ & $\mathbf{1 2 9 1}$ & $\mathbf{1 2 7 8}$ \\
\hline
\end{tabular}

Although the number of teachers and schools in Lithuania is constantly decreasing (Table 1), a great deal of attention is paid to pedagogue qualification improvement in the country. Teachers are still prone to constant improvement of their skills, they realize the requirements of continuous learning that are underlined by the scientists (Dukynaitè, 2005).

\section{ANALYSIS OF TEACHER'S PROFESSIONAL DEVELOPMENT IN LITHUANIA}

Teachers' professional development in Lithuania is an open system which is regulated exceptionally by financial opportunities and quality requirements. This system is a constituent part of non-formal education of adults defining the rights and duties of pedagogues and ensuring the assistance to school and pedagogues.

Professional development of teachers is organized by the Ministry of Education, universities, the Education Development Centre, and other educational and research institutions subordinate to the Ministry, as well as by the municipal administrations, training institutions (educational centres, continuing education institutes etc.) and freelance teachers, who have right to engage in the teacher training programs.

TALIS (2009) survey ascertained that on average across 23 participating countries, almost $89 \%$ of teachers reported engaging in some professional development (defined as having taken part in at least one day of development in the previous 18 months) over the survey period. When participation rates are compared across 
countries, there are some notable differences. Lithuania ranks among the countries in which teachers participate most actively (95.5\%). Teachers participate more actively in their professional improvement only in Spain (100\%), Slovenia (97\%), Australia (97\%) and Austria (97\%). This contrasts with the situation in Denmark (76 \%), Iceland (77\%), Slovakia and Turkey (both $75 \%$ ), where around one quarter reported no participation during the period. Greece did not take part in this survey. In the European Union context, Lithuania's results with respect to the number of teachers participating in professional development are quite good. However, differently from the teachers of other countries, Lithuanian teachers have little interest in the global issues, they still are reluctant to share their practical expertise, participate in professional networks or relate their professional career to qualification upgrading.

Although the function of a continuous professional development is decentralized and has been delegated to educational centres and non-profit organizations, the Ministry of Education reserves the right to set priorities and allocate the funds. The Education Development Centre under the Ministry of Education and Science is responsible for the development and coordination of the professional development programme. Other educational institutions involved in the professional development of teachers are responsible for qualification upgrading courses/programmes.

University centres rendering professional development services organize and develop multi-disciplinary professional training and retraining; teacher training is only part of work accomplished by these centres. Their services vary both in terms of the nature and content of programmes. All university centres implementing professional development programmes seek to attract both the academic community and the school community.

Higher education institutions have not yet used all favorable conditions provided in the sphere of professional development of teachers, especially regarding cooperation with teachers and schools, the exchange of professional ideas and development of partnership, as well as participation in the creation of cooperation networks of regional educational organizations. 
Pursuant to the research, the existing system for the professional development of teachers only partially meets the needs of pedagogues. In order to ensure high quality of their professional development it is necessary to create the system to monitor quality of these programmes. Specialists providing teacher training services are prepared pursuant to programmes for training of these specialists (teachers of higher education institutions, school teachers, education managers) approved and accredited by the Government of the Republic of Lithuania, and according to the requirements stipulated in relevant regulatory enactments.

Mostly professional development courses/seminars for pedagogues are prepared by the teachers practitioners and teachers of different subjects. These specialists are not specifically trained (except certain cases) for this particular activity. The requirements for specialists providing professional development services are defined by the client ordering the above service (Dačiulytè, Dromantienè and e.c, 2012).

The situation related to the professional development of pedagogues is evaluated as satisfactory due to the well-developed system of education centres, higher responsibility, and attribution of this activity to the local level. Negative aspects of professional development of pedagogues are related to the insufficient control of quality of professional development events, different interests of teachers and school administration, and inappropriate use of funds allocated for professional development.

The main qualification requirements for specialists providing professional development services are: the master's degree of the field where courses are organised, and the experience in the professional development of pedagogues. Lectors are invited depending on the area of their expertise, qualification skills, the requests of the course participants, recommendations and evaluations of course participants.

According to data from educational centres (Dačiulytè, Dromantienè and e.c, 2012) organizing professional development courses for pedagogues, participants want to be taught by the pedagogues-practitioners who are well aware of the practical aspects of their subject. 
In order to ensure high quality of the implemented programmes, they should be accredited. Institutional programmes evaluated by the accredited institutions are considered as the accredited programmes. Institutional level programmes are evaluated according to the Procedure for the Evaluation of Programmes approved by the accredited institutions. The institution shall submit the evaluated institutional level programmes to the Centre for registration. The programmes pursued outside the territory of the Republic of Lithuania cannot be equaled to the accredited programmes and shall be submitted to the Centre for accreditation according to the established procedure. All programmes pursued outside the territory of Lithuania shall be accredited by experts selected by the Centre.

Pursuant to the analysis of the quality of professional development the planned evaluation is related to the accreditation of programmes. The analysis of the officially submitted information revealed that there were no manifestations of the formative evaluation. Most often the summative evaluation is applied; it is based on the reactions of participants of the professional development courses. "Qualification improvement of Lithuanian pedagogues is based on provisions that are common with Europe and underline changing pedagogue's role in the knowledge based society and new competencies and values that are necessary to a modern pedagogue" (Čiužas, Briedis, Adaškevičienè (2005)

In order to evaluate the changes in every teacher's qualifications during the professional development course, it is necessary to develop and implement the mechanism defining the impact of professional development courses on teachers' work results.

\section{CONCLUSIONS}

Although the function of continuous qualification improvement is essentially decentralized and a wide network of the institutions of pedagogue qualification improvement is at work in Lithuania, however the Ministry of Education and Science of Lithuania still retains the function of priorities setting and resources allocation. The most important institutions that perform the functions of organization and implementation of teachers' qualification improvement at municipality level are education centres that conduct researches of needs, organize qualification improvement and rescaling, and create conditions for dissemination of good practice. 
The functions of organization and implementation of teachers' qualification improvement at municipality level are performed by other centres, higher education institutions and their subdivisions.

The training of specialists, that perform the activity of teachers' qualification improvement, especially for this activity (except for special cases) is not performed. Requirements for the qualification of specialists that provide the services of pedagogue qualification improvement are defined by the client in every concrete case when ordering service.

It has been ascertained that when evaluating qualification improvement programs summative assessment that is based on the reflection of participants on the qualification improvement events, is most often applied. Educology scientists do not conduct targeted researches of Lithuanian pedagogue qualification improvement processes and the influence of the service on education, only solitary, quite specialized problematic questions, quite rarely and indirectly linking them with teachers' qualification improvement are analysed.

A teacher's transition from one career stage to another is related to the certification procedure, which is mandatory for all teachers regardless of their career aspirations. Certification in a certain sense is an overview of the training process. 


\section{REFERENCES}

2012 Council Conclusions on a Strategic Framework for European Cooperation in Education and Training ("ET 2020"); project Education and Training in the Progressive, Sustainable and Integrated Europe. Brussels, 2011.12.20 $\operatorname{COM}(2011)$

Čiužas R., Briedis M., Adaškevičienė M. (2005) Europinès švietimo dimensijos kaip pedagogu kvalifikacijos tobulinimosi veiksnys Lisabonos strategijos kontekste// Mokytoju ugdymas. Nr. 4, p. 16-23.

Creating Effective Teaching and Learning Environments. Firs Results from TALIS (2009) OESD. [interactive: http://www.oecd.org/edu/school/43023606.pdf], [ viewed 201310 27]

Dačiulytè, R., Dromantienè, L., Indrašienè, V., Merfeldaitè, O., Nefas, S., Penkauskienè, D., Prakapas, R., Railienè, A. (2012). Model for the Professional Development of Pedagogues. Vilnius, [interactive: http://www.upc.smm.It/projektai/pkt/naujienos/modelis/PKT modelis.pdf] [viewed 30/09/2012]

Dromantiene, L. Zemaitaityte, I. (2010) Participation of adults in lifelong learning in Lithuania: Motivations and Possibilities // Learning in Transition. Policies and Practicies of Lifelong Learning in Post-Socialist Countries. St Peterburg: Nauka.

Dromatienè L., Kanopienè V., Mikulionienè S., Norvilè N., Žemaitaitytè, I. (2009) The survey of Lithuanian adult learners' participation in formal education. Standard tabulations and main data. Vilnius: Mykolas Romeris University.

Dukynaitè R. (2005) Gimnaziju pedagogu kvalifikacijos kèlimo ypatumai // Pedagogika. T. 79, p. p. 80-84.

Hargreaves, A. Teaching in the Knowledge Society. Vilnius: Homo liber, 2008. Jarvis P. Besimokanti visuomenè - šiuolaikinio pasaulio reiškinys // Mokykla. Nr. 1-2. 1997

Law amending the Law on Education of the Republic of Lithuania. Official Gazette. 2011. No 38-1804

Lisbon Strategy, 2000.

Murphy, I. \& Coolahan, J. Attracting, Developing and Retaining Effective Teachers. Country Background Report for Ireland., OECD, 2003, [interactive], [viewed 12/04/2013]， <http://www.oecd.org/edu/preschoolandschool/19196740.pdf> 
National Education Strategy for 2013-2022 [interactive], [viewed 12/04/2013] <http://www.smm.lt>.

National Lisbon Strategy Implementation Programme. Official Gazette. 2005. No 1395019

Pečiuliauskienè, P. (2005). Kvalifikacijos tobulinimo sistemos pokyčiai: humanitariniu, socialiniu ir realiniu dalyku mokytoju požiūris // Pedagogika. T. 77, p. 78-83.

Rado, P. Education during the transitional period. Vilnius: Garnelis, 2003.

Ross, A. \& Hutchings, M. Attracting, Developing and Retaining Effective Teachers in the United Kingdom of Great Britain and Northern Ireland, OECD Country Background Report. OECD, 2003, [interactive], [viewed 12/04/2013], <http://www.oecd.org/education/school/2635748.pdf>

Rutkienè, A., Zuzevičiūtè, V. Changing Role of the Teacher: Engagement of Community in Pursuance of More Effective Learning. Pedagogika. 2009, 95, p. 53-57

Strategy for the Assurance of Lifelong Learning. Official Gazette. 2004. No 561957.

Stylianidou, F. et all. Attracting, Developing and Retaining Effective Teachers. Country Background Report for Greece., OECD, 2004, [interactive], [viewed 12/04/2013]， <http://www.oecd.org/edu/preschoolandschool/greece.pdf>

Teachers professional development. Europe in international comparison, 2010, Luxembourg: Office for Official Publications of the European Union, [interactive], [viewed 12/04/2013], <http://ec.europa.eu/education/schooleducation/doc/talis/report en.pdf>

The Concept of Education in Lithuania. Vilnius: Publishing Centre, 1992.

Trakšelys, K. Teachers' qualification development: element of professionalization// Andragogika. No1. P 45-48, 2011.

Tuovinen, J. E. 'Teacher Professionalism - Viewpoints on Best Practice, the Case of Finland'// Paper presented to the scientific conference AARE 2008, Brisbane, Australia, 2008.

Žygaitienè B., Barkauskaitè M., Miškinienè M. (2013) Professional Competences of a Teacher during the Period of Educational Paradigm Transformation in Lithuania // Procedia - Social and Behavioral Sciences. Vol. 83, p.165-169. 
of cognitive development and aging. Developmental Review, 12, 45-75.

Denollet, J. \& De Vries, J. (2006). Positive and negative affect within the realm of depression, stress and fatigue: The two-factor distress model of the Global Mood Scale (GMS). Journal of Affective Disorders, 91(2):171-180.

Dusek, J. B. (1980). The development of test anxiety in children. In I. G. Sarason (Ed.), Test anxiety: Theory, research and applications (pp. 87-110). Hillsdale, $\mathrm{NJ}$ : Erlbaum.

Egede, L. \& Ellis, C. (2010). Diabetes and depression: Global perspectives. Diabetes research and clinical practice, $87,302-312$.

Folstein 